\title{
Biomass and net primary productivity of mangrove communities along the Oligohaline zone of Sundarbans, Bangladesh
}

\author{
Md. Kamruzzaman ${ }^{1,2^{*}}$, Shamim Ahmed ${ }^{2}$ and Akira Osawa ${ }^{1}$
}

\begin{abstract}
Background: The article presents the first estimates of biomass and productivity for mangrove forests along the Oligohaline zone of the Sundarbans Reserve Forest (SRF), Bangladesh. This study was conducted overone year from March 2016 to April 2017. Stand structure, above and below-ground biomass changes, and litterfall production were measured within a $2100 \mathrm{~m}^{2}$ sample plot.

Methods: All trees in the study plots were numbered and height $(H)$ and diameter at breast height $(D B H)$ were measured. Tree height $(H)$ and DBH for each tree were measured in March 2016 and 2017. We apply the above and belowground biomass equation for estimating the biomass of the mangrove tree species (Chave et al. Oecologia 145:87-99, 2005; Komiyama et al. J Trop Ecol 21:471-477, 2005). Litterfall was collected using 1-mm mesh litter traps with collection area of $0.42 \mathrm{~m}^{2}$. Net Primary Production (NPP) was estimated by the summation method of Ogawa Primary productivity of Japanese forests: productivity of terrestrial communities, JIBP synthesis (1977) and Matsuura and Kajimoto Carbon dynamics of terrestrial ecosystem: Systems approach to global environment (2013).

Results: Heritiera fomes has maintained its dominance of the stand and also suffered the highest tree mortality (2.4\%) in the suppressed crown class. The total above-ground biomass (AGB) and below-ground biomass (BGB) of

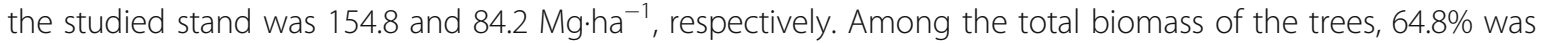
allocated to $A G B$ and $35.2 \%$ to BGB. In case of species-wise contribution of biomass allocation, Avicennia officinalis showed the highest score and Aglaia cucullata the lowest. Mean annual total litterfall was $10.1 \mathrm{Mg} \cdot \mathrm{ha}^{-1} \cdot \mathrm{yr}^{-1}$, with the maximum litterfall in winter or dry season and late summer or rainy season. The mean AGB increment and

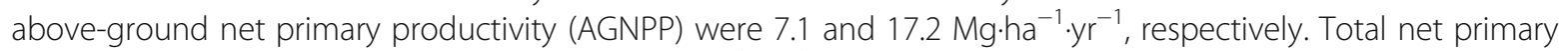
productivity (NPP) was estimated to be $21.0 \mathrm{Mg} \cdot h \mathrm{a}^{-1} \cdot \mathrm{yr}^{-1}$ over the observed period. The results in the Sundarbans mangrove forests exhibited that mangrove communities with similar height and diameter produced different biomass production with the different basal area. The present analysis revealed that the root biomass was large enough and the mean ratio of above-/below-ground biomass was estimated to be 1.84 .
\end{abstract}

Conclusions: Mangrove communities growing at the oligohaline zone of the Sundarbans, Bangladesh showed high biomass and net primary production indicating their ecological and conservation significance that may be considered in future decision making process for the area as well as in understanding the role of Sundarbans mangrove forest on mitigating the effect of global warming.

Keywords: Primary production, Litterfall, Monthly pattern, Biomass carbon, Species wise contribution, Sundarbans

\footnotetext{
* Correspondence: zaman_dulu@yahoo.com

'Laboratory of Ecosystem Production and Dynamics, Graduate School of

Global Environmental Studies, Kyoto University, Kyoto 606-8501, Japan

${ }^{2}$ Forestry and Wood Technology Discipline, Khulna University, Khulna 9208,

Bangladesh
} 


\section{Background}

Mangrove forests play an important role in the functioning of tropical coastal ecosystems (Day et al. 1987), as well as unique wetland ecosystems in intertidal coastal regions of the tropics and subtropics (Lugo and Snedaker 1975; Nagarajan et al. 2008). Mangroves are also important contributors of nutrients to estuarine and inshore productivity through litterfall. Litterfall is a valuable indicator of their productivity and it is the most easily measured component of total net primary productivity (Day et al. 1987; Mackey and Smail 1995). Biomass and net primary productivity of mangrove forest have been studied previously in different mangrove forests across the world (e.g., Putz and Chan 1986; Day et al. 1987, 1996; Saintilan 1997; Komiyama et al. 2000; Kamruzzaman et al. 2017) and the purposes of their biomass estimation and productivity are mainly related to consideration of ecosystem management and evaluation of carbon stock (Tamai et al. 1986, Komiyama et al. 1987, 2000).

The Sundarbans, the world's largest continuous patch of mangrove forest, is located in the estuary of the river Ganges-Brahmaputra. The forest is distributed over two neighboring countries, Bangladesh and India. In Bangladesh, the forest covers $6017 \mathrm{~km}^{2}\left(21^{\circ} 30^{\prime}-22^{\circ} 30^{\prime} \mathrm{N}\right.$, $\left.89^{\circ} 00^{\prime}-89^{\circ} 55^{\prime} \mathrm{E}\right)$. It is the first mangrove forest in the world which has been brought under scientific management since 1982, thereafter no apparent forest harvest and catastrophic disturbance have occurred. As recently as 200 years ago the Sundarbans extended across most of southwestern Bangladesh (Islam 2001). From the available literature it is known that during the period 1873-1933, the forest was reduced from 7599 to $6000 \mathrm{~km}^{2}$ (Curtis 1933; Blasco 1977; Iftekhar and Saenger 2008) and in the recent years the boundary is almost same as $6017 \mathrm{~km}^{2}$. Chaffey et al. (1985) divided the Sundarbans mangrove forest into three ecological zones viz. fresh water (Oligohaline), moderately saline water (Mesohaline) and salt water (Polyhaline) zones. Based on salinity distribution, three salinity zones: Oligohaline (salinity $<2 \mathrm{dsm}^{-1}$ ), Mesohaline (salinity 2-4 $\left.\mathrm{dsm}^{-1}\right)$, Polyhaline $\left(>4 \mathrm{dsm}^{-1}\right)$ zones could be recognized (Siddiqi 2001). Changes in salinity might be responsible for the spatial distribution of plant communities (Ahmed et al. 2011).

Our study was conducted in a mangrove community within the Oligohaline zone of the Sundarbans, Bangladesh. A few studies have been conducted, such as allometry, biomass and carbon storage of the Sundarbans Reserve Forest (SRF), Bangladesh with respect to its biodiversity and role in carbon sink among the other forest ecosystems in the tropics (Iftekhar and Saenger 2008; Ahmed et al. 2011; Rahman et al. 2015; Hossain et al. 2015). However, no studies were found in literature that evaluated net primary productivity of the mangrove communities in this area.
Thus, the objective of this study was to determine net primary productivity of mangrove forests along the Oligohaline zone of SRF. Its relationship to different parameters were also examined and presented. For the majority of mangrove studies, dead tree biomass was excluded and litterfall was measured just for a short period (Christensen 1978; Day et al. 1987; Hernádez et al. 2011). However, in this study, we examined 2 years of data for each of the components and took into account tree mortality during calculation of net primary productivity.

\section{Methods \\ Study site}

The study was conducted in Dhangmari, Karamjol, and Ghagramari areas of SRF, Bangladesh, over 1 year from March 2016 to April 2017. This area receives regular tidal inundation through the River Passur. The mean annual rainfall in the region varies from about $2000 \mathrm{~mm}$ in the east and $1600 \mathrm{~mm}$ in the west. The rainy season is from June to September. October to February is considered winter and a drier season. Higher temperatures $\left(26{ }^{\circ} \mathrm{C}-34{ }^{\circ} \mathrm{C}\right)$ occur during March and June and lower temperatures $\left(12{ }^{\circ} \mathrm{C}-25{ }^{\circ} \mathrm{C}\right)$ during December and February. The annual relative humidity varies from 70 to 80\% (Rahman and Asaduzzaman 2010). We established 21 plots $(10 \mathrm{~m} \times 10 \mathrm{~m})$, which are located in the Oligohaline zone of the Sundarbans, covering $2100 \mathrm{~m}^{2}$ where all were considered around $200 \mathrm{~m}$ away from the shore for avoiding destruction of the plot due to river erosion and damages due to storms. All trees in the study plots were numbered and height $(H)$ and diameter at breast height $(\mathrm{DBH})$ were measured. Tree height $(H)$ and $\mathrm{DBH}$ for each tree were measured in March 2016 and 2017. Some error in measuring tree growth was likely because only 1 year of DBH change was recorded.

\section{Biomass estimation}

Although allometric relationships have been developed between $\mathrm{DBH}$ and weight for a number of mangrove species around the world, biomass production depends on the interaction between edaphic, climatic and topographic factors of the specified area and the species that occurred on the specific area. Unfortunately there is only one developed allometric equation for biomass estimation of the studied mangrove species encountered in this study. The above-ground biomass of each individual of $E$. agallocha was estimated using allometric relationships between DBH and biomass, established by Hossain et al. (2015). So we tentatively apply the following aboveground biomass equation for the other mangrove tree species (Chave et al. 2005).

$$
\begin{gathered}
\mathrm{AGB}=\rho \times \exp \left(-1.349+1.980 \ln (D)+0.207(\ln (D))^{2}\right. \\
\left.-0.0281(\ln (D))^{3}\right)
\end{gathered}
$$


where AGB $=$ aboveground biomass, $\rho=$ wood density, $D=\mathrm{DBH}$. The wood density data were obtained from Global Wood Density Database (Chave et al. 2009).

Below-ground biomass of mangrove tree species was estimated using common allometric relationships between DBH and biomass, established by Komiyama et al. (2005).

$$
\mathrm{BGB}=\left(0.199, \rho^{0.899} D^{2.22}\right)
$$

where $\mathrm{BGB}=$ belowground biomass, $\rho=$ wood density, $D=\mathrm{DBH}$.

Individual tree's biomass calculation for each species and its increment for each tree were estimated using the same allometric equation. The common allometric relationship for root weight was derived from the relationship between below-ground and above-ground weight of trees, so wood density is the same for both above-ground and belowground weight estimation.

\section{Litterfall collection}

Litterfall was collected using 1-mm mesh litter traps with collection area of $0.42 \mathrm{~m}^{2}$. Two litter traps were placed in each $10 \mathrm{~m} \times 10 \mathrm{~m}$ plot at $>1 \mathrm{~m}$ high from the ground to avoid tidal water, i.e., a total of 42 litter traps were placed within the 21 plots. The litter traps were emptied monthly; the collected litterfall was kept in a cotton bag and carried to the laboratory where it was separated into leaves, stipules, branches, flower buds, flowers, and propagules. Individual litterfall components were dried at $80{ }^{\circ} \mathrm{C}$ for $48 \mathrm{~h}$, desiccated at room temperature, and then weighed using a digital balance (EK-600H, A \& D Co., Ltd., Tokyo, Japan).

\section{Net primary production}

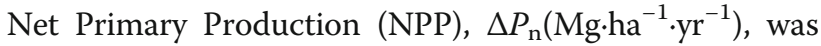
estimated by the summation method of Ogawa (1977) and Matsuura and Kajimoto (2013) as follows:

$$
\Delta P_{\mathrm{n}}=\Delta y+\Delta L+\Delta G
$$

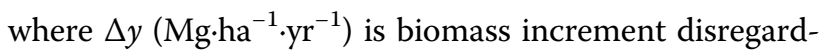

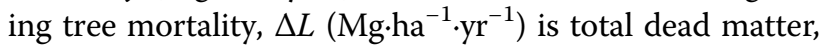
which is sum of total litter production and amount of dry matter due to tree mortality, and $\Delta G\left(\mathrm{Mg} \cdot \mathrm{ha}^{-1} \cdot \mathrm{yr}^{-1}\right)$ is amount of grazing. We do not account for direct herbivory in this study, therefore, $\Delta G$ is negligibly small in the present study area, and $\Delta G$ is ignored in the current study (Kamruzzaman et al. 2017).

\section{Results}

\section{Community structure and composition}

Mangrove species and their structural characteristics in the study area along the oligohaline zone of SRF were presented in Table 1. A total of six mangrove species
Table 1 Stand structure data of mangrove communities along

\begin{tabular}{|c|c|c|c|c|c|}
\hline Year & Species & $\begin{array}{l}\text { Density } \\
\left(\mathrm{ha}^{-1}\right)\end{array}$ & $\begin{array}{l}\text { Mean basal } \\
\text { area } \\
\left(\mathrm{m}^{2} \cdot \mathrm{ha}^{-1}\right)\end{array}$ & $\begin{array}{l}\text { Mean } \\
\text { DBH } \\
(\mathrm{cm})\end{array}$ & $\begin{array}{l}\text { Mean } \\
H(\mathrm{~m})\end{array}$ \\
\hline \multirow[t]{6}{*}{2016} & $\begin{array}{l}\text { Heritiera fomes } \\
\text { Buch-Ham. }\end{array}$ & \multirow[t]{6}{*}{$2338 \pm 233$} & \multirow[t]{6}{*}{$22.6 \pm 4.1$} & \multirow[t]{6}{*}{$9.0 \pm 1.0$} & \multirow[t]{6}{*}{$9.1 \pm 0.8$} \\
\hline & $\begin{array}{l}\text { Excoecaria } \\
\text { agallocha L. }\end{array}$ & & & & \\
\hline & $\begin{array}{l}\text { Bruguiera } \\
\text { sexangula } \\
\text { (Lour.) Poir. }\end{array}$ & & & & \\
\hline & $\begin{array}{l}\text { Avicennia } \\
\text { officinalis } \mathrm{L} \text {. }\end{array}$ & & & & \\
\hline & $\begin{array}{l}\text { Xylocarpus } \\
\text { mekongensis J. } \\
\text { Koenig }\end{array}$ & & & & \\
\hline & $\begin{array}{l}\text { Aglaia cucullata } \\
\text { (Roxb.) Pellegr. }\end{array}$ & & & & \\
\hline \multirow[t]{6}{*}{2017} & H. fomes & \multirow[t]{6}{*}{$2305 \pm 235$} & \multirow[t]{6}{*}{$22.7 \pm 3.9$} & \multirow[t]{6}{*}{$9.3 \pm 0.8$} & \multirow[t]{6}{*}{$9.3 \pm 1.1$} \\
\hline & E. agallocha & & & & \\
\hline & B. sexangula & & & & \\
\hline & A. officinalis & & & & \\
\hline & X. mekongensis & & & & \\
\hline & A. cucullata & & & & \\
\hline
\end{tabular}
the Oligohaline zone of Sundarbans, Bangladesh

belonging to five families were observed in the tree layer: Heritiera fomes, Excoecaria agallocha, Xylocarpus mekongensis, Bruguiera sexangula, Avicennia officinalis, and Aglaia cucullata. The mean density, height, DBH, and wood density of $H$. fomes, E. agallocha, X. mekongensis, B. sexangula, A. officinalis, and A. cucullata were indicated in Table 2 . Tree density decreased with increasing age of the stand. The mortality rate of $H$. fomes was the highest than other species. The highest mortality was suffered by small size $H$. fomes (2.4\%) trees in the suppressed crown class. No mortality was occurred in the rest of the species during the study period. Figure 1 showed the relationship between mean $\mathrm{DBH}$ and mean height of different plots of the studied stands. Tree height of the mangrove stands revealed positive correlation with tree $\mathrm{DBH}$. This pattern means that tree height is increased with increasing DBH.

\section{Aboveground and belowground biomass}

Table 3 showed the biomass production and proportions of biomass apportioned to the different components of the trees. The mean values of above-ground and belowground biomass of the stand were $154.8 \pm 3.5$ and $84.2 \pm 1.9 \mathrm{Mg} \cdot \mathrm{ha}^{-1} \cdot \mathrm{yr}^{-1}$, respectively, which accounted for $64.8 \%$ and $35.2 \%$, respectively, of the total tree biomass. Figure 2 showed the species-wise contribution in biomass allocation among the different components. Of these, $A$. officinalis accounted for $40.3 \%$ and $36.6 \%$, which was the 
Table 2 Specific density, species wise DBH, $\mathrm{H}$ and wood density in different plot location in mangrove communities along the Oligohaline zone of Sundarbans

\begin{tabular}{lllllll}
\hline Plot location & Number of species & Species & Specific density $\left(\mathrm{ha}^{-1}\right)$ & Mean DBH $(\mathrm{cm})$ & Mean $H(\mathrm{~m})$ & Wood density \\
\hline Dhangmari & 3 & H. fomes & 1214 & $6.2 \pm 0.3$ & $7.0 \pm 0.3$ & 0.816 \\
& & E. agallocha & 533 & $6.7 \pm 0.4$ & $7.9 \pm 0.4$ & 0.480 \\
Karamjol & 5 & X. mekongensis & 229 & $11.5 \pm 0.8$ & $10.7 \pm 0.7$ & 0.620 \\
& & B. sexangula & 176 & $14.7 \pm 1.0$ & $9.8 \pm 0.6$ & 0.740 \\
Ghagramari & 5 & A. officinalis & 110 & $30.0 \pm 2.3$ & $23.5 \pm 1.2$ & 0.590 \\
& & A. cucullata & 24 & $5.4 \pm 0.6$ & $4.1 \pm 0.4$ & 0.620 \\
\hline
\end{tabular}

highest contributor both in above-ground biomass and below-ground biomass production, respectively. The above- and below-ground biomass was plotted against structural parameters of the stand such as mean height, mean DBH, and basal area (Fig. 3). Correlation analysis between biomass of the studied species with their respective mean height, mean $\mathrm{DBH}$, and basal area exhibited the arrangement of the communities according to their degree of preponderance. The communities with high above- and below-ground biomass had greater values of basal area. The total biomass of the studied plots ranged from $22.8 \mathrm{Mg} \cdot \mathrm{ha}^{-1}$ (Plot 20) to $1135.0 \mathrm{Mg} \cdot \mathrm{ha}^{-1}$ (Plot 16). The total basal area of the plots ranged from $3.9 \mathrm{~m}^{2} \cdot \mathrm{ha}^{-1}$ (Plot 20) to $85.5 \mathrm{~m}^{2} \cdot \mathrm{ha}^{-1}$ (Plot 16). The extreme variation in basal area and biomass is partly the result of edge effects associated with the very small plot size. This pattern also indicates that basal area may be a predictor of total biomass of trees in the mangrove stands. Figure 4 showed a relationship between $\mathrm{AGB} / \mathrm{BGB}$ and tree density. There is no correlation between them.

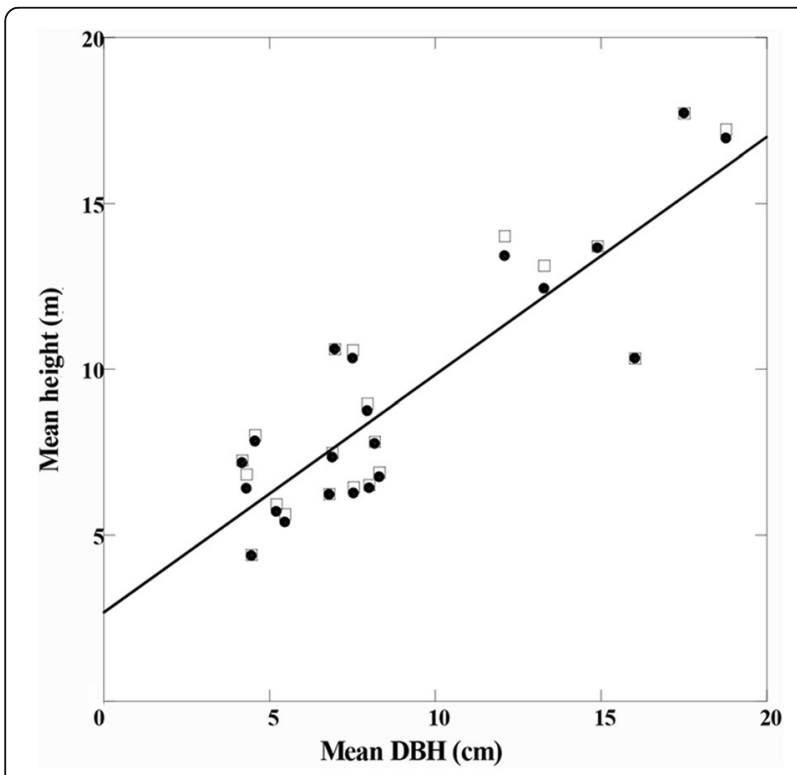

Fig. 1 Relationship between mean $\mathrm{DBH}$ and height of trees in the study area $\left(R^{2}=0.79\right) ; \bullet: 2016 ;$; 2017

\section{Litterfall}

Litterfall were observed throughout the year, and we were so far unable to separate the litterfall components at the species level. The study area consists of six mangrove species and out of these $X$. mekongensis and $E$. agallocha are deciduous species and the rest are evergreen species. Figure 5 showed the seasonality of the litterfall of all the mangrove species. Leaf-fall was the dominant component of litterfall throughout the year. There were definite peaks in each litterfall component. However, litterfall amounts of leaf, branch, and reproductive organs did not show any clear monthly patterns of the mixed mangrove species. Because leaf shedding and leaf emergence times were mixed among the evergreen and deciduous species. For example, the leaf shedding time of $X$. mekongensis started in December and continued until March, i.e., winter and spring seasons, whereas leaf shedding of $E$. agallocha started from February and continued until May, i.e., spring season. The highest peak of leaf litterfall was in February, i.e., winter season and the next highest peak was observed in July, i.e., in the late summer or rainy season. Branch litterfall was high in June-July (rainy season), and this may be due to strong rain and storms at that time. Reproductive organ litterfall was highest in March, i.e., in the spring season when almost all studied mangrove species started their flowering. Young, tender, green, and yellow leaves contributed the most to total litterfall. Mean values of litterfall in leaf, branch, and reproductive organ $( \pm \mathrm{SE})$ were $7.1 \pm 0.05,1.3 \pm 0.02$ and $1.7 \pm 0.02 \mathrm{Mg} \cdot \mathrm{ha}^{-1} \cdot \mathrm{yr}^{-1}$, respectively, which represented $70.2 \%, 12.9 \%$ and $16.9 \%$ of the total litterfall, respectively.

\section{Net primary productivity}

The mean biomass increment and mean litterfall was 7.1 and $10.1 \mathrm{Mg} \cdot \mathrm{ha}^{-1} \cdot \mathrm{yr}^{-1}$, respectively for the mangrove community (Table 4). One-year measurement is usually not sufficient to obtain a reliable estimate of long term average mortality rate. Therefore, tree mortality is negligibly small in the present study and we simply summed the biomass increment of all the surviving trees and then added litterfall 
Table 3 Biomass and its contribution in the mangrove forest along the Oligohaline zone of Sundarbans, Bangladesh

\begin{tabular}{llllll}
\hline Year & AGB $\left(\mathrm{Mg} \cdot \mathrm{ha}^{-1}\right)$ & BGB $\left(\mathrm{Mg}^{-} \mathrm{ha}^{-1}\right)$ & Tree biomass $\left(\mathrm{Mg} \cdot \mathrm{ha}^{-1}\right)$ & $\begin{array}{l}\text { AGB } \\
(\% \text { of TB) }\end{array}$ & $\begin{array}{l}\text { BGB } \\
(\% \text { of TB })\end{array}$ \\
\hline 2016 & 151.3 & 82.3 & 233.6 & 64.8 & 35.2 \\
2017 & 158.3 & 86.1 & 244.4 & 64.8 & 35.2 \\
Mean & $154.8 \pm 3.5$ & $84.2 \pm 1.9$ & $239.0 \pm 5.4$ & 64.8 & 35.2 \\
\hline
\end{tabular}

to get the above-ground net primary productivity for each small plot. Above-ground net primary production (AGNPP) was 17.2 Mg.ha ${ }^{-1} \cdot \mathrm{yr}^{-1}$. Mean below ground increment was estimated to be $3.8 \mathrm{Mg} \cdot \mathrm{ha}^{-1} \cdot \mathrm{yr}^{-1}$. Similarly, belowground production includes increment of roots of living trees plus turn of fine roots. Most of this turnover is the mortality of fine roots of living trees, same as the litterfall of above-ground components. But in this study, we were unable to measure the fine root production, so our assessment of below-ground production did not include fine root turnover. NPP for both aboveground and belowground combined was $21.0 \mathrm{Mg} \cdot \mathrm{ha}^{-1} \cdot \mathrm{yr}^{-1}$ during the study period. AGNPP contributed $81.9 \%$ of the total NPP and belowground contributed $18.1 \%$ of the total NPP.

\section{Discussion}

Stand density (2305 $\mathrm{ha}^{-1}$ ) of the present study area was comparable to mature riverine mangroves or mixed mangrove stands (3310-3917 $\mathrm{ha}^{-1}$ ) at French Guiana (Fromard et al. 1998). They reported higher density at pioneer stage



Fig. 2 Species-wise contribution in total biomass allocation of mangrove forest along the oligohaline zone of the Sundarbans, Bangladesh; solid dark column: AGB; open column: BGB of mangrove species than its mature stage. In the present study we observed that communities with small sized trees had very high density; while communities with large sized trees had lower density. This is in agreement with Fromard et al. (1998) suggesting that density was the most discriminating factor for early development stage of mangroves- a young stand matures by decreasing the number of individuals. The present study showed that mangrove communities with similar mean height and mean diameter produced different biomass production with different basal area (Fig. 2). For example, mean height $(6.5 \mathrm{~m})$ and mean DBH $(6.4 \mathrm{~cm})$ of a particular stand showed a large difference in biomass production (127-279 ${\mathrm{Mg} \cdot \mathrm{ha}^{-1} \text { ) and (84-279 Mg.ha }}^{-1}$ ), respectively. This variation is due to the differences in basal area of the stand. These results are generally consistent with the findings of Fromard et al. (1998), who observed that large biomass differences (180-315 th.ha ${ }^{-1}$ ) for Avicennia germinans populations with similar height and diameter but with different basal area.

\section{Aboveground and belowground biomass}

This study showed that the mean above-ground biomass of $154.8 \mathrm{Mg} \cdot \mathrm{ha}^{-1}$ was within the documented range of $40.70-279.03 \mathrm{Mg} \cdot \mathrm{ha}^{-1}$ in the mangrove forests of East Sumatra, Indonesia (Kusmana et al. 1992), or of $123.5-383.5 \mathrm{Mg} \cdot \mathrm{ha}^{-1}$ in the mangrove forests of Dominican Republic (Sherman et al. 2003). The present value of AGB was almost identical to that (159 $\left.\mathrm{Mg} \cdot \mathrm{ha}^{-1}\right)$ of Rhizophora apiculata Bl. dominated mangrove forest in southern Thailand (Christensen 1978) and (163 Mg.ha ${ }^{-1}$ ) of B. gymnorrhiza dominated forest along the Okukubi River, Okinawa Island, Japan (Kamruzzaman et al. 2017). This value was higher than those reported for subtropical mixed mangrove forest at Ishigaki Island, southern Japan (78.6 Mg.ha ${ }^{-1}$; Suzuki and Tagawa 1983). The present value of accumulation of mean aboveground biomass was within the converted range of AGB from aboveground biomass carbon for Sundarbans mangrove forests (55.3-153.4 Mg.ha ${ }^{-1} \mathrm{C}$; Chanda et al. 2016). Compared to the previous studies, the present study indicates that biomass productivity of the mangrove species in the present study was relatively high among the mangrove forests in the tropical and subtropical areas, showing that mean annual wood production of $7.1 \mathrm{Mg} \cdot \mathrm{ha}^{-1} \cdot \mathrm{yr}^{-1}$. A 

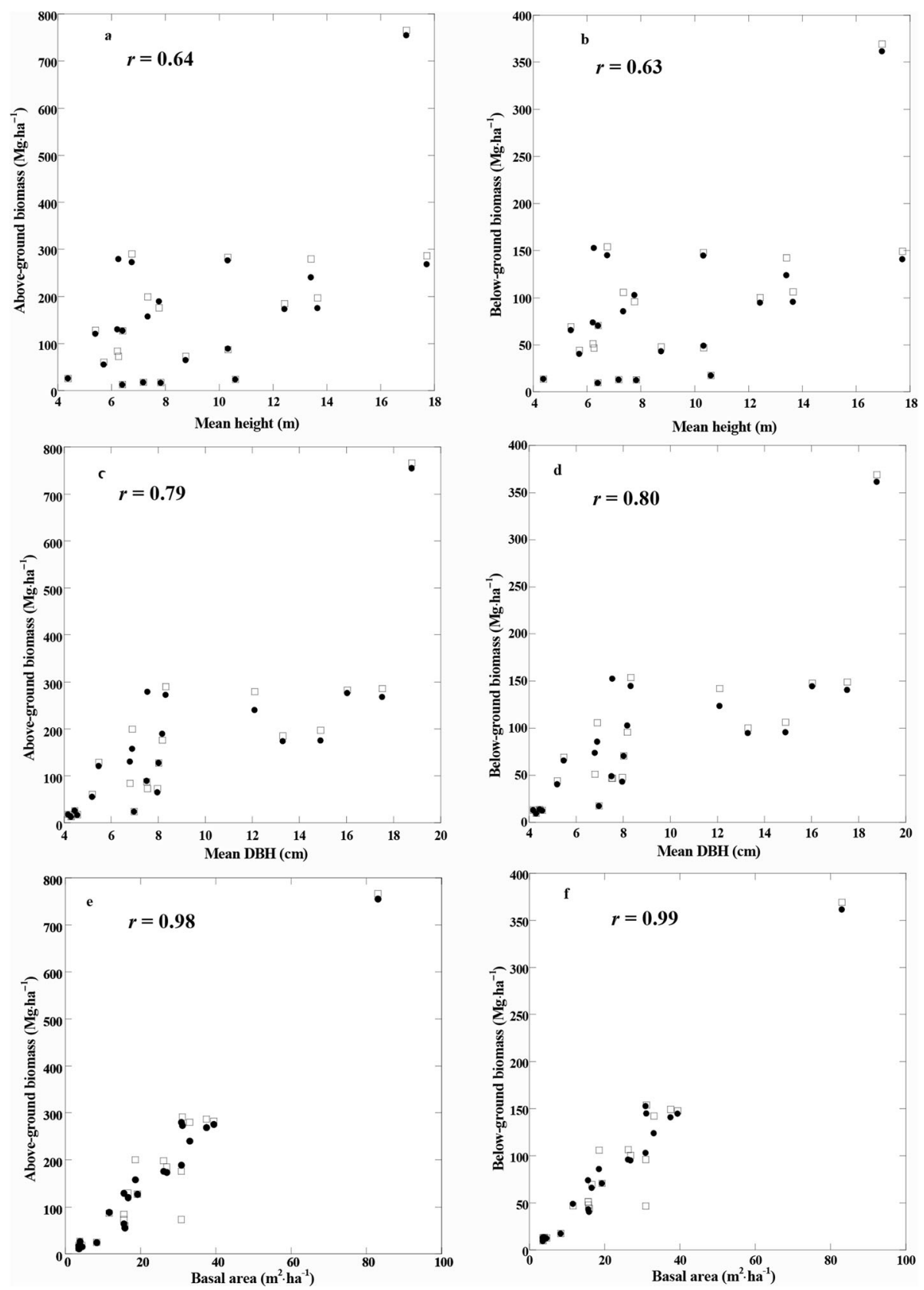

Fig. 3 a-f Relationships between biomass and main structural parameters of mangrove communities; $\bullet: 2016$; $\square$ : 2017

similar observation was made by Putz and Chan (1986), who reported that the average stem production over 31 years for a Rhizophora-Bruguiera forest in Malaysia was $6.7 \mathrm{Mg} \cdot \mathrm{ha}^{-1} \cdot \mathrm{yr}^{-1}$. The mean value of AGB increment was higher than the $5.9 \mathrm{Mg} \cdot \mathrm{ha}^{-1} \cdot \mathrm{yr}^{-1}$ recorded on $R$. stylosa dominated mangrove forest at Missionary Bay, Hinchinbrook Channel, Australia (Clough 1998). It is important to mention that AGB of the studied mangrove communities is accounted for mainly due to stem biomass and is also a permanent indicator of biomass increment. Small branches and leaves mainly contributed in the litterfall production.

The mean above/below-ground biomass ratio of the present stand was 1.84. This value is higher than the records for Ceriops tagal (Perr.) C. B. Rob. at southern Thailand (1.05; Komiyama et al. 2000) and for B. gymnorrhiza at Okinawa Island, Japan (1.3; Kamruzzaman et al. 2017). This mean value is similar with records for other mangrove species at New South Wales (1.3-2.0; Saintilan 1997). The present value of above-/belowground ratio is lower than trees of the terrestrial inland 




Fig. 4 Relationship between AGB/BGB and density; •:2016; $\square: 2017$

forest of tropical areas (5.1-10.7; Ogawa et al. 1965; Hozumi et al. 1969). It indicates that a major portion of biomass is allocated to the underground parts in the present studied mangrove species than in terrestrial plants so the above-/below-ground ratio in Sundarbans mangroves is generally lower than terrestrial plants. Mangroves are usually coping a saline environment with the stress of high water tables but physiologically dry condition for the plants and deficiency of oxygen (Ball 1988; Havanond and Maxwell 1996), so a large portion

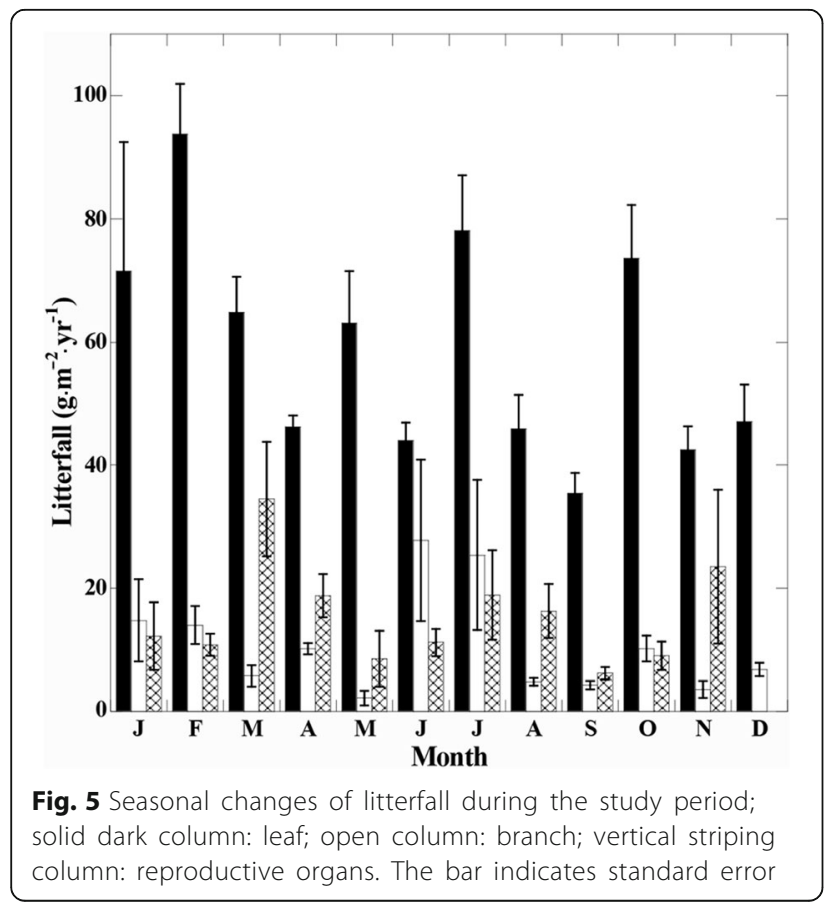

Table 4 Mean annual net primary production and its components of mangrove forest (Mg.ha ${ }^{-1} \cdot \mathrm{yr}^{-1}$ ) along the Oligohaline zone of the Sundarbans, Bangladesh

\begin{tabular}{lllll}
\hline Component & Leaf & Branch & Reproductive organ & Total \\
\hline Mean AGB increment $(\Delta \mathrm{y})$ & - & - & - & 7.1 \\
Mean litterfall $\left(\Delta \mathrm{L}_{\mathrm{f}}\right)$ & 7.1 & 1.3 & 1.7 & 10.1 \\
AGNPP & - & - & - & 17.2 \\
Mean BGB increment & - & - & - & 3.8 \\
Net primary production & - & - & - & 21.0 \\
\hline
\end{tabular}

of biomass is allocated to the underground parts of the mangrove species to adapt to the harsh environment. A low above/below-ground ratio of biomass was also reported in a larch ecosystem that grows on permaforest. This larch species must also cope with a harsh environment of limited soil nutrients and low soil temperature (Kajimoto et al. 2010), showing similarity to the mangrove communities of the present study as well as to the mangrove forest at Okinawa Island, Japan (Kamruzzaman et al. 2017).

\section{Litterfall}

This is the first report of litterfall production of the Sundarbans mangrove forest, Bangladesh. The mean total litterfall production (10.1 Mg.ha ${ }^{-1} \cdot \mathrm{yr}^{-1}$ ) of the present mangrove forest was within the documented range for mangrove forests at Laguna de Términos, Mexico (8.4-12.5 Mg.ha ${ }^{-1} \cdot \mathrm{yr}^{-1}$; Day et al. 1987), in

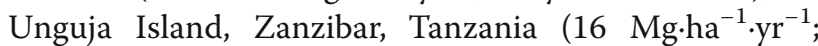
Shunula and Whittick 1999), and at Central Java, Indonesia (7.1-10.4; Sukardjo 1996). The mean total litterfall of the present study was higher than those recorded on southeastern Mexican mangrove forest (3.1-7.9 Mg.ha-1 $\cdot \mathrm{yr}^{-1}$; Day et al. 1996). Mangrove leaves are shed continuously throughout the year especially in case of a community of mixed mangrove species. Day et al. (1987) reported that higher productivity in mangroves is related to higher input of nutrients. Thus, regular tidal inundation, lower salinity level, and regular nutrient input may be the factors related to higher mean productivity in the present study. This study showed that maximum leaf litterfall of the investigated species occurred in winter or dry season and late summer or rainy season. In many mangrove areas, similar findings were observed that peak litterfall occurs during the rainy season (Leach and Burgin 1985; Day et al. 1987) and FloresVerdugo et al. (1987) reported high litterfall at the end of the dry season. In the tropics, where temperatures are always favorable for tree growth, seasonal development is often not correlated with climate. In tropical rain forest many trees flush and flower at the same specie-specific time each year, but 
others do so at irregular intervals (Borchert 2017). The tropical climate could cause multimodal peaks of leaf litterfall in mangroves in this region.

\section{Net primary productivity}

This is the first report of net primary productivity of the Sundarbans Mangrove forest, Bangladesh. The present stand had above-ground biomass of $154.8 \mathrm{Mg} \cdot \mathrm{ha}^{-1} \cdot \mathrm{yr}^{-1}$, and above-ground net primary production during the study period was estimated to be $17.2 \mathrm{Mg} \cdot \mathrm{ha}^{-1} \cdot \mathrm{yr}^{-1}$. Those values were lower to those of AGB (159 Mg.ha ${ }^{-1} \cdot \mathrm{yr}^{-1}$ ) and AGNPP (27 Mg.ha $\left.{ }^{-1} \cdot \mathrm{yr}^{-1}\right)$ for R. apiculata dominated mangrove forest at Southern Thailand (Christensen 1978). Our estimates of AGNPP (17.2 Mg.ha $\left.{ }^{-1} \cdot \mathrm{yr}^{-1}\right)$ were near the high end of the range of values reported in mangrove forests at Florida, USA (8.1-26.1 Mg.ha ${ }^{-1} \cdot \mathrm{yr}^{-1}$; Ross et al. 2001). The present value of NPP was higher than those reported for $R$. apiculata dominated forest at Matang mangrove forest, Malaysia (17.7 Mg.ha ${ }^{-1} \cdot \mathrm{yr}^{-1}$; Putz and Chan 1986). The study area is located in the oligohaline zone of the Sundarbans mangrove forest and the area is flushed frequently by tides that may cause higher NPP of this mangroves. Similar findings were observed by Day et al. (1989), who reported that mangrove forest flushed frequently by tides and exposed to high nutrient concentrations have higher net primary production. There are three ecological zones in the Sundarbans such as oligohaline, mesohaline, and polyhaline zone based on the degree of salinity and floristic composition. The floristics composition of Sundarbans is defined by the distribution of three species: H. fomes, E. agallocha, and $C$. decandra. All three species occur throughout the Sundarbans but in different proportions depending on salinity. H. fomes is the characteristics of the oligohaline zone, E. agallocha of the mesohaline zone, and $C$. decandra of the polyhaline zone (Rahman and Islam 2015). Depending on the site of mangroves along the salinity gradient of an estuary and with distance inland from the shore, the properties of mangrove communities vary within an environmental setting (Chen and Twilley 1999). So in the present study, mangrove communities in the oligohaline zone may have higher productivity and turnover than other ecological zones of Sundarbans, Bangladesh.

When comparing our estimated rates of litterfall and biomass increment both in AGB and BGB, it becomes evident that litterfall production only amount up to $48.1 \%$ of the total mangrove NPP. There are very few reports that describe the contribution of litterfall to total NPP, and reported that litterfall represents up to $30 \%$ of the overall NPP (Alongi et al. 2005). NPP of the mangrove forest along the oligohaline zone of Sundarbans, Bangladesh, is conservative and the estimation was lower because we do not have data regarding coarse root and fine root production and their contribution is not included. As well as we do not have any data regarding vegetative damage including leaf and reproductive organs by direct consumption of the herbivory animals. The ratio of AGNPP and litterfall of the present study was 1.7:1. Our results agree with the summarization of Teas (1979), who reported that the assumption of total AGNPP for mangroves is three times as large as the amount of total litterfall.

\section{Conclusion}

It is not possible to clearly determine how much difference there are in the production of mangrove forests among different studies, due to differences in methodology, inter-annual variation, site condition, and stage of mangrove development. Moreover, there is no standard technique to compare the production capability of the mangrove stands all over the world. It is concluded that, the results of the first study at Sundarbans, Bangladesh indicate that the biomass accumulation (239 $\left.\mathrm{Mg} \cdot \mathrm{ha}^{-1}\right)$ and productivity (21.0 $\mathrm{Mg} \cdot \mathrm{ha}^{-1} \cdot \mathrm{yr}^{-1}$ ) of the Sundarbans mangrove forest, Bangladesh contribute significantly to global carbon budget because higher biomass accumulation, higher productivity and large area of the remaining mangrove communities spanning two countries (Bangladesh and India) are related to higher carbon turnover of the stand in absolute terms. The unique characteristics of the Sundarbans mangrove forest also provide important information to decision makers on the strategy for sustainable management of the mangrove forests.

\section{Acknowledgments \\ This work was supported by a Grant-in-Aid for Scientific Research (JSPS KAKENHI 15F15389) from the Japan Society for the promotion of Science to Professor Akira Osawa and Md. Kamruzzaman. The authors are grateful to the Forest Department, Govt. of the People's Republic of Bangladesh for establishing the research plots in the SRF and for assisting the research team in collecting data. The authors are grateful to Mrs. Minhaj-Uz-Siraj, Kalan Basak, and Sumanto Paul for their invaluable assistance during field data collection.}

\section{Author's contributions}

Md.K developed the concept of the article. Md.K also established the plots, forest inventory and acquired the data. SA helped in data collection. Md.K worked on the manuscript preparation and $A O$ edited the draft manuscript and all authors read and approved the final manuscript.

\section{Competing interests}

The authors declare that they have no competing interests.

Received: 6 June 2017 Accepted: 29 August 2017

Published online: 27 September 2017

\section{References}

Ahmed A, Aziz A, Khan AZMNA, Islam MN, lqbal KF, Nazma IMS (2011) Tree diversity as affected by salinity in the Sundarban mangrove forests, Bangladesh. Bangladesh J Bot 40:197-202

Alongi DM, Clough BF, Robertson Al (2005) Nutrient-use efficiency in arid-zone forests of the mangroves Rhizophora stylosa and Avicennia marina. Aquat Bot $82: 121-131$ 
Ball MC (1988) Salinity tolerance in mangroves Aegiceras corniculatum and Avicennia marina. I. Water use in relation to growth, carbon partitioning, and salt balance. Aust J Plant Physiol 15:447-464

Blasco F (1977) Outlines of ecology, botany and forestry of the mangals of the Indian subcontinent. In: Chapman VJ (ed) Wet coastal ecosystems, ecosystems of the world, vol 1. Elsevier, Amsterdam, pp 241-260

Borchert R (2017) The phenology of tropical trees. http://www.borchert.faculty.ku. edu. Accessed 18 May 2017

Chaffey DR, Miller FR, Sandom JH (1985) A forest inventory of the Sundarban, Bangladesh. Project Report 140, Land Resources Development Centre, Surrey, England. 196

Chanda A, Mukhopadhyay A, Ghosh T, Akhand A, Mondal P, Ghosh S, Mukherjee S, Wolf J, Lázár AN, Rahman MM, Salehin M, Chowdhury SM, Hazra S (2016) Blue carbon stock of the Bangladesh Sundraban mangroves: what could be the scenario after a century? Wetlands 36:1033-1045

Chave J, Andalo C, Brown S, Cairns MA, Chambers JQ, Eamus D, Fölster H, Fromard F, Higuchi N, Kira T, Lescure JP, Nelson BW, Ogawa H, Puig H, Riéra B, Yamakura T (2005) Tree algometry and improved estimation of carbon density and balance in tropical forests. Oecologia 145:87-99

Chave J, Coomes DA, Jansen S, Lewis SL, Swenson NG, Zanne AE (2009) Towards a worldwide wood economics spectrum. Ecol Lett 12:351-366

Chen R, Twilley RR (1999) Patterns of mangrove forest structure and oil nutrient dynamics along the shark river estuary, Florida. Estuaries 22:955-970

Christensen B (1978) Biomass and primary production of Rhizophora apiculata BI. In a mangrove in southern Thailand. Aquat Bot 4:43-52

Clough B (1998) Mangrove forest productivity and biomass accumulation in Hinchinbrook Channel, Australia. Mangr Salt Marsh 2:191-198

Curtis SJ (1933) Working plan for the forests of the Sundarbans Division for the period from $1^{\text {st }}$ April 1931 to $31^{\text {st }}$ March 1951, Voulme III Part of Appendix III Description of the Compartments and their Histories. Government of Bengal

Day JW, Conner WH, Ley-Lou F, Day RH, Navarro AM (1987) The productivity and composition of mangrove forests, Laguna De Términos, Mexico. Aquat Bot 27:267-284

Day JW, Coronado-Molina C, Vera-Herrera FR, Twilley R, Rivera-Monroy VH, Alvarez-Guillen H, Day R, Conner W (1996) A 7 year record of aboveground net primary production in a southern Mexican mangrove forest. Aquat Bot 55:39-60

Day JW, Hall C, Kemp M, Yáňez-Arancibia A (1989) Estuarine ecology. Wiley Interscience, New York, p 558

Flores-Verdugo FJ, Day JW, Briseňo-Dueňas R (1987) Structure, litterfall, decomposition, and detritus dynamics of mangroves in a Mexican coastal lagoon with ephemeral inlet. Mar Ecol Prog Ser 35:51-56

Fromard F, Puig H, Mougin E, Marty G, Betoulle JL, Cadamuro L (1998) Structure, above-ground biomass and dynamics of mangrove ecosystems: new data from French Guiana. Oecologia 115:39-53

Havanond S, Maxwell GS (1996) Strategies for mangrove restoration. FORTROP 10:21-36

Hernádez CMA, Zaragoza CG, Iriarte-Vivar S, Flores-Verdugo FJ, Casasola PM (2011) Forest structure, productivity and species phenology of mangroves in the la Mancha lagoon in the Atlantic coast of Mexico. Wetl Ecol Manag 19:273-293

Hossain M, Siddique MRH, Saha S, Abdullah SMR (2015) Allometric models for biomass, nutrients and carbon stock in Excoecaria agallocha of the Sundarbans, Bangladesh. Wetl Ecol Manag 23:765-777

Hozumi K, Yoda K, Kokawa S, Kira T (1969) Production ecology of tropical rain forest in southern Cambodia I. Plant biomass. Nat Life Se Asia 6:1-51

Iftekhar MS, Saenger P (2008) Vegetation dynamics in the Bangladesh Sundarbans mangroves: a review of forest inventories. Wetl Ecol Manag 16: 291-312

Islam MS (2001) Sea-level changes in Bangladesh: the last ten thousand years. Asiatic Society of Bangladesh, Dhaka

Kajimoto T, Osawa A, Usoltsev VA, Abaimov AP (2010) Biomass and productivity of Siberian Larch forest ecosystems. In: Osawa A, Zyryanova OA, Matsuura Y, Kajimoto T, Wein RW (eds.) Permafrost Ecosystems: Siberian Larch forests. Ecological studies, Springer 209:99-122

Kamruzzaman M, Osawa A, Deshar R, Sharma S, Mouctar K (2017) Species composition, biomass, and net primary productivity of mangrove forest in Okukubi River, Okinawa Island, Japan. Regional Studies in Marine Science 12:19-27
Komiyama A, Havanond S, Srisawatt W, Mochida Y, Fujimoto K, Ohnishi T, Ishihara S, Miyagi T (2000) Top/root biomass of a secondary mangrove (Ceriops tagal (Perr.) C.B. Rob.) forest. Forest Ecol Manag 139:127-134

Komiyama A, Ogino K, Aksomkoae S, Sabhasri S (1987) Root biomass of a mangrove forest in southern Thailand I. Estimation by the trench method and the zonal structure of root biomass. J Trop Ecol 3:97-108

Komiyama A, Poungparn S, Kato S (2005) Common allometric equations for estimating the tree weight of mangroves. J Trop Ecol 21:471-477

Kusmana C, Sabiham S, Abe K, Watanabe H (1992) An estimation of above ground tree biomass of a mangrove forest in East Sumatra, Indonesia. Tropics 1:243-257

Leach GJ, Burgin S (1985) Litter production and seasonality of mangroves in Papua New Guinea. Aquat Bot 23:215-224

Lugo AE, Snedaker SC (1975) Properties of a mangrove forest in southern Florida. In: Walsh G, Snedaker S, Teas H (eds) Proceedings of the international symposium on biology and management of mangroves. University of Florida, Gainesville, pp 170-212

Mackey AP, Smail G (1995) Spatial and temporal variation in litterfall of Avicennia marina (Forssk.) Vierh. In the Brisbane River, Queensland, Australia. Aquat Bot 52:133-142

Matsuura Y, Kajimoto T (2013) Measurement and analysis of Carbon pool and flow by the ecological approach. In: Oikawa T, Yamamoto $S$ (eds) Carbon dynamics of terrestrial ecosystem: Systems approach to global environment. Kyoto University press, p 414

Nagarajan B, Pandiarajan C, Krishnamoorthy M, Sophia P (2008) Reproductive fitness and success in mangroves: implication on conservation. In: Sengupta M, Dalwani R (eds) Proceedings of Tall 2007: the $12^{\text {th }}$ World Lake Conference, pp 29-33

Ogawa H (1977) Principles and methods of estimating primary production in forests. In: Shidei T, Kira T (eds) Primary productivity of Japanese forests: productivity of terrestrial communities, JIBP synthesis. University of Tokyo Press, pp 29-37

Ogawa H, Yoda K, Ogino K, Kira T (1965) Comparative ecological studies on three main type of forest vegetation in Thailand. Nat Life Se Asia 4:49-80

Putz FE, Chan HT (1986) Tree growth, dynamics, and productivity in a mature mangrove forest in Malaysia. Forest Ecol Manag 17:211-230

Rahman MR, Asaduzzaman M (2010) Ecology of Sundarban, Bangladesh J Sci Foundation 8:35-47

Rahman MM, Islam SA (2015) Phenophase of five mangrove species of the Sundarbans of Bangladesh. IJBSC Res 4:77-82

Rahman MM, Khan MNI, Hoque AKF, Ahmed I (2015) Carbon stock in the Sundarbans mangrove forest: spatial variations in vegetation types and salinity zones. Wetl Ecol Manag 23:269-283

Ross MS, Ruiz PL, Telesnicki GJ, Meeder JF (2001) Estimating above-ground biomass and production in mangrove communities of Biscayne National Park, Florida (USA). Wetl Ecol Manag 9:27-37

Saintilan N (1997) Above- and below-ground biomasses of two species of mangrove on the Hawkesbury River estuary, new South Wales. Mar Freshw Res 48:147-152

Sherman RE, Fahey TJ, Martinez P (2003) Spatial patterns of biomass and aboveground net primary productivity in a mangrove ecosystem in the Dominican Republic. Ecosystems 6:384-398

Shunula JP, Whittick A (1999) Aspects of litter production in mangroves from Unguja Island, Zanzibar, Tanzania. Estuar Coast Shelf Sci 49:51-54

Siddiqi NA (2001) Mangrove forestry in Bangladesh. Institute of Forestry and Environmental Sciences. University of Chittagong, Chittagong

Sukardjo S (1996) The relationship of litterfall to basal area and climatic variables in the Rhizophora Mucronata Lamarck plantation at Tritih, central java, Indonesia. J Southeast Asian Stud 34:424-432

Suzuki E, Tagawa H (1983) Biomass of a mangrove forest and a sedge marsh on Ishigaki Island, South Japan. Jap J Ecol 33:231-234

Tamai S, Nakasuga T, Tabuchi R, Ogino K (1986) Standing biomass of mangrove forests in southern Thailand. J Jpn Fo Soc 68:384-388

Teas HJ (1979) Silviculture with saline water. In: Hollander A, Aller JC, Epstein E, Pietro AS, Zaborsky OR (eds) The baseline concept. Plenum Press, New York, pp 117-161 